\title{
TECHNICAL SCIENCE
}

\section{Method of applying two-step variational-gradient method to dynamic models in decision support systems}

\author{
*N. B. Dakhno, T. V. Maisak, H. V. Shevchenko, O. V. Svynchuk \\ State University of Telecommunications, Kyiv, Ukraine \\ Kyiv National Economic University named after Vadym Hetman, Kyiv, Ukraine \\ *Corresponding author. E-mail: Nataly.Dakhno@ukr.net
}

Paper received 31.01.19; Accepted for publication 08.02.19.

\section{https://doi.org/10.31174/SEND-NT2019-193VII23-19}

Abstract. Dynamic models of decision support systems for controlling unmanned aerial vehicles are considered. Dynamic models are described by equations with K-positive definite K-symmetric operators. The method of two-step variational-gradient type application, which consists of algorithms and corresponding block diagrams, is presented. The developed method provides an opportunity to optimally implement a two-step variational-gradient method in the process of automating control of unmanned aerial vehicles.

Keywords: dynamic models, decision support system, flight mission, unmanned aerial vehicles, variation-gradient method.

Introduction. Systems of support and decision-making are a qualitatively new level of automation of managerial decisions with remote control of unmanned aerial vehicles (UAVs). The remote control system is responsible for scheduling the flight task, forming teams when changing the flight path by the pilot-operator, adjusting the parameters of the automatic control system, displaying telemetry information, analyzing flight data, and managing the UAV's payload.

Operational flexibility, the a+++++bility to transmit information received in real time and receive timely information at any step of the flight to obtain the necessary data for its analysis and decision making, makes it expedient to develop modern methods for substantiating and synthesizing UAV control systems as complex dynamic systems.

The analysis of the last studies and publications. Recently, considerable attention is paid to the use of decision support systems (DSS) for the management of UAVs [1-3]. Problems of synthesis of systems for the automatic control of movement of aircraft, including unmanned ones, are devoted to work [4-6].

Despite a large number of scientific publications in these areas, modern methods of controlling aircraft, such as theoretical research methods for dynamics of controlled systems, variation calculations and optimal control, are not sufficiently used.

Unfortunately, almost all current trajectory planning methods used in modern UAV control systems are resource intensive.

\section{Main part}

1. The problem setting. The basis of DSS for automated control is the formal description - the mathematical model of the decision-making situation. Models of decision support systems described by dynamic models provide a sufficiently complete description of the situations that arise when managing objects.

In the classical analysis, many techniques and methods for studying dynamic models [7-9] have been developed. Among a variety of methods, the most commonly used computational practice is using approximate methods, which include variational, projection and differential methods, and iterative methods. On the basis of direct and iterative methods, variational-gradient-type methods have appeared, including two-step variational-gradient method. The algorithm of a two-step variational-gradient method does not require knowledge of the spectrum of the operator, is resistant to perturbations and has a good convergence rate. Therefore, actual and promising is the development and improvement of variational-gradient methods.

2. The algorithm of two-step variation-gradient method. We will consider dynamic DSS models for operating UAVs in operator form, that is, models are described by equations or systems of the equations of the form:

$A u=f, f \in H$,

The operator $A: D(A) \rightarrow H$ is defined on a dense in $H$ set $D(A)$, and is linear $K$-positive and $K$-symmetric, that is there is an operator $K: D(K) \rightarrow H, D(K) \subset D(A)$, which allows closing in $H$ and:

$$
\begin{aligned}
& \exists \alpha, \beta>0:(A u, K u) \geq \alpha\|u\| 2, \forall u \in D(A), \\
& \|K u\| 2 \leq \beta(A u, K u), \forall u \in D(A), \\
& (A u, K v)=(A v, K u), \forall u, v \in D(A),
\end{aligned}
$$

Let's assume that there is linear $K$-positive and $K$ symmetric operator $B: D(B) \rightarrow H$ i $D(B)=D(A)$ and it's easy to find its converse operator $B^{-1}$.

Let the condition be fulfilled:

$\exists \gamma, \delta>0: 0<\gamma<\delta<\infty, \forall u \in D(A)$ $\gamma(B u, K u) \leq(A u, K u) \leq \delta(B u, K u) \quad 5)$

Under conditions (2) - (5) an equation (1) has the only generalized solution [10] and solution of the equation (1) is equivalent to finding the minimum of a functional:

$F(u)=(A u, K u)-2(f, K u)$

Let's consider the equation (1) and assume that the conditions (2) - (5) are fulfilled.

Let $H_{0}$ is some Hylbert subspace such that $H_{0} \subset D(A) \subset H$ and $u_{0} \in D(A)-$ is an arbitrary initial approximation. Assume that the $k$-th approximation is found, then the following approximations are in the scheme:

$u_{k+1}=x_{k}+w_{k}, w_{k} \in H_{0}$,

here an element $x_{k}$ is defined from the equation:

$B x_{k}=B u_{k}+\alpha B \delta_{k}+\beta_{k} r_{k}$

$B x_{0}=B u_{0}+\beta_{0} r_{0}$

here $\delta_{k}=u_{k}-u_{k-1}, r_{k}=f-A u_{k},-$ is a mismatch 
Unknown parameters $\alpha_{k}, \beta_{k}$ and element $w_{k}$ are found from the functional minimization condition (6):

$$
F\left(u_{k+1}\right)=\left(A u_{k+1}, K u_{k+1}\right)-2\left(f, K u_{k+1}\right)
$$

As $B$ has the conversed operator then (7) - (9) can be rewriting as:

$$
\begin{aligned}
u_{k+1}=u_{k}+ & \alpha_{k} \delta_{k}+\beta_{k} B^{-1} r_{k}+w_{k} \\
u_{1}=u_{0}+ & \beta_{0} B^{-1} r_{0}+w_{0} \\
& \alpha_{k}\left(A \delta_{k}, K \delta_{k}\right)+\beta_{k}\left(A B^{-1} r_{k}, K \delta_{k}\right)+\left(A w_{k}, K \delta_{k}\right)=\left(r_{k}, K \delta_{k}\right) \\
& \alpha_{k}\left(A \delta_{k}, K B^{-1} r_{k}\right)+\beta_{k}\left(A B^{-1} r_{k}, A B^{-1} r_{k}\right)+\left(A w_{k}, A B^{-1} r_{k}\right)=\left(r_{k}, A B^{-1} r_{k}\right) \\
& \alpha_{k}\left(A \delta_{k}, K v\right)+\beta_{k}\left(A B^{-1} r_{k}, K v\right)+\left(A w_{k}, K v\right)=\left(r_{k}, K v\right), \forall v \in H_{0} .
\end{aligned}
$$

In case $H_{0}$ is the subspace originated by the system or linear in dependent elements $\left\{\varphi_{i}: i \geq 1\right\} \subset H_{0}$, then the correction in (11) will be found in the form: $w_{k}=\sum_{i=1}^{n} a_{i}^{k} \varphi_{i}$, where $\left\{a_{i}^{k}: k \geq 1,1 \leq i \leq n\right\} \subset R$.

$$
\begin{aligned}
& \alpha_{k}\left(A \delta_{k}, K \delta_{k}\right)+\beta_{k}\left(A B^{-1} r_{k}, K \delta_{k}\right)+\sum_{i=1}^{n} a_{i}^{k}\left(A \varphi_{i}, K \delta_{k}\right)=\left(r_{k}, K \delta_{k}\right) \\
& \alpha_{k}\left(A \delta_{k}, K B^{-1} r_{k}\right)+\beta_{k}\left(A B^{-1} r_{k}, A B^{-1} r_{k}\right)+\sum_{i=1}^{n} a_{i}^{k}\left(A \varphi_{i}, A B^{-1} r_{k}\right)=\left(r_{k}, A B^{-1} r_{k}\right) \\
& \alpha_{k}\left(A \delta_{k}, K \varphi_{j}\right)+\beta_{k}\left(A B^{-1} r_{k}, K \varphi_{j}\right)+\sum_{i=1}^{n} a_{i}^{k}\left(A \varphi_{i}, K \varphi_{j}\right)=\left(r_{k}, K \varphi_{j}\right), j=\overline{1, n} .
\end{aligned}
$$

The system (16) - (18) has a single solution relative $\alpha_{k}, \beta_{k}$ and $a_{i}^{k}$.

Theorem. If the operator $A$ satisfies conditions (2) - (5) in equation (1), $u_{0}$ is the initial approximation found by the Ritz method, then the two-step variational-gradient method (7) - (15) coincides and the rate of convergence is characterized by an estimation:

$$
\left\|u^{*}-u_{k}\right\|_{B} \leq q_{k} \sqrt{\frac{1}{\sigma \gamma}}\left\|B^{-1}\left(f-A u_{0}\right)\right\|_{B^{\prime}}
$$

here $q_{k}=\frac{2 \xi^{k}}{1+\xi^{2 k}}, \xi=\frac{\sqrt{\sigma}-\sqrt{\eta}}{\sqrt{\sigma}+\sqrt{\eta}}$

3. Method of application of two-step variationgradient method for DSS models with K-positively defined, K-symmetric operator. For practical implementation of the method it is reasonable to use the following scheme:

Let $y_{0} \in D(A)$ - be an arbitrary initial approximation $\left\{\varphi_{i}: i \geq 1\right\} \subset H_{0}$ is the complete system of linearly in dependent elements, $\varepsilon>0$ is the required accuracy of the solution sought, $k$ is the iteration number.

1. Initialization of the initial data $y_{0}, \varepsilon, k=1$.

2. Calculation of the first approximation according to onestep variational-gradient method according to the corresponding algorithm.

Note that according to one-dimensional variationalgradient method, we have calculated the following expressions:

$$
\begin{aligned}
& d_{i j}=\left(A \varphi_{i}, K \varphi_{j}\right) ; \quad D=\left(\begin{array}{cccc}
d_{11} & d_{12} & \ldots & d_{1 n} \\
d_{21} & d_{22} & \ldots & d_{2 n} \\
d_{n 1} & d_{n 2} & \ldots & d_{n n}
\end{array}\right) \text {; } \\
& D^{-1} ; \bar{b}=\left(\begin{array}{c}
b_{1} \\
b_{2} \\
\cdots \\
b_{n}
\end{array}\right)
\end{aligned}
$$

3. $\mathrm{k}=\mathrm{k}+1$.
12)

Then the relations (13) - (15) are converted into a system of linearly in dependent equations:

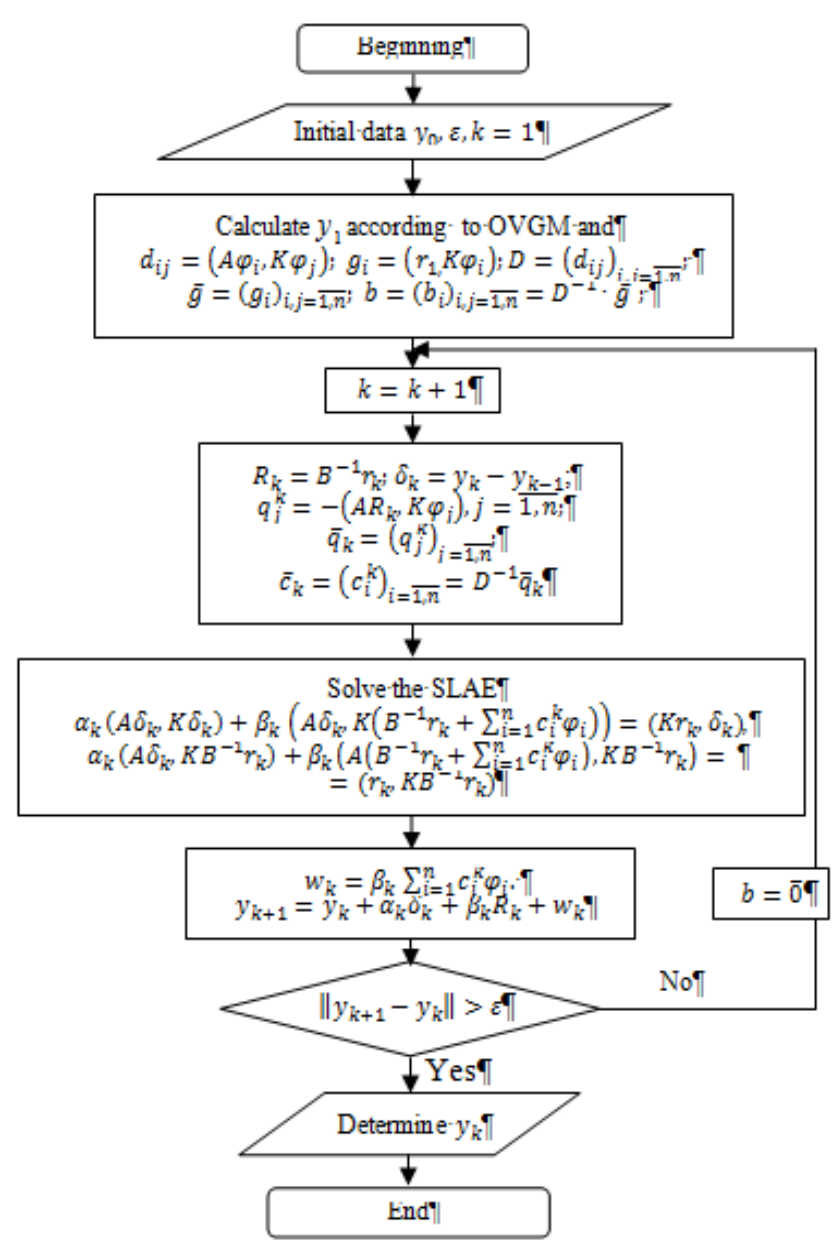

Fig.1. Block diagram of the two-step algorithm a method

4. Calculate the expressions:

$\mathrm{r}_{\mathrm{k}}=\mathrm{f}-\mathrm{Ay}_{\mathrm{k}-1} ; \mathrm{R}_{\mathrm{k}}=\mathrm{B}^{-1} \mathrm{r}_{\mathrm{k}} ; \mathrm{AR}_{\mathrm{k}} ; \mathrm{KR}_{\mathrm{k}}$;

$\delta_{\mathrm{k}}=\mathrm{y}_{\mathrm{k}}-\mathrm{y}_{\mathrm{k}-1} ; \mathrm{A} \delta_{\mathrm{k}} ; \mathrm{K} \delta_{\mathrm{k}}$.

5. Calculate the constants $\overline{\mathrm{c}_{\mathrm{k}}}$ for the corrections $\mathrm{w}_{\mathrm{k}}$ : 
$\mathrm{q}_{\mathrm{j}}^{\mathrm{k}}=-\left(\mathrm{AR}_{\mathrm{k}}, \mathrm{K} \varphi_{\mathrm{j}}\right), \mathrm{j}=\overline{1, \mathrm{n}} ;$
$\overline{\mathrm{q}}_{\mathrm{k}}=\left(\mathrm{q}_{\mathrm{j}}^{\mathrm{k}}\right)_{\mathrm{j}=\overline{1, \mathrm{n}}} ; \overline{\mathrm{c}}_{\mathrm{k}}=\left(\mathrm{c}_{\mathrm{i}}^{\mathrm{k}}\right)_{\mathrm{i}=\overline{1, \mathrm{n}}}=\mathrm{D}^{-1} \overline{\mathrm{q}}_{\mathrm{k}}$
6. Calculation of the parameters $\alpha_{k} \mathrm{i} \beta_{k}:$
$h_{11}^{k}=\left(A \delta_{k}, K \delta_{k}\right) ;$
$h_{12}^{k}=\left(A \delta_{k}, K\left(R_{k}+\sum_{i=1}^{n} c_{i}^{k} \varphi_{i}\right)\right)$
$h_{21}^{k}=\left(A \delta_{k}, K R_{k}\right) ;$
$h_{22}^{k}=\left(A\left(B^{-1} r_{k}+\sum_{i=1}^{n} c_{i}^{k} \varphi_{i}\right), K B^{-1} r_{k}\right)$
$l_{1}^{k}=\left(\delta_{k}, K r_{k}\right) ; l_{2}^{k}=\left(r_{k}, K R_{k}\right) ;$
$\left(\begin{array}{l}\alpha_{k} \\ \beta_{k}\end{array}\right)=\left(\begin{array}{ll}h_{11}^{k} & h_{21}^{k} \\ h_{12}^{k} \quad h_{22}^{k}\end{array}\right) \cdot\left(\begin{array}{l}l_{1}^{k} \\ l_{2}^{k}\end{array}\right)$.
7. Calculation of the correction $w_{k}:$
If $k=2: w_{2}=-\alpha_{2} \sum_{i=1}^{n} b_{i} \varphi_{i}+\beta_{2} \sum_{i=1}^{n} c_{i}^{2} \varphi_{i}$
if $k \geq 3: w_{k}=\beta_{k} \sum_{i=1}^{n} c_{i}^{k} \varphi_{i}$.
8. Calculation of the approximation:
$y_{k+1}=y_{k}+\alpha_{k} \delta_{k}+\beta_{k} R_{k}+w_{k}$.
9. Condition fulfilling control: if $\left\|y_{k+1}-y_{k}\right\|>\varepsilon$, then $\bar{b}=\overline{0}$ and repeat $3-9$.

Block scheme for this algorithm is shown in Fig.1.

6. Discussion of the integration of the variational gradient method in to the control system of an unmanned aerial vehicle results. Synthesis of variational and gradient methods can eliminate the disadvantages inherent in these methods. According to the estimates obtained in the theorem, a two-step variational-gradient method has a good convergence rate, is resistant to perturbations and does not require knowledge of the boundaries of the spectrum of the operator. Therefore, the study of a dynamic model with the help of two-step variational-gradient method will increase the efficiency of information processing in decision-making processes in the control of UAVs.

At the same time, it should be noted that in practice it is not always possible to construct an adequate model in a linear analytical form. This complicates the use of the variational-gradient in DSS. Therefore, further development of the theory of variational-gradient methods is to extend these methods to broader models of models. Of particular interest is the consideration of non linear cases. The complexity of the propagation of variational-gradient methods to the non linear equation is the need to obtain linear systems for determining the parameters for constructing the approximation.

Conclusion. Developing an approach to formulate recommendations for the timely adoption of informed decisions by the operator in the remote control of the UAV is an urgent problem. One of the directions that can significantly improve the efficiency of the solution of the tasks of the flight is the analysis of dynamic models in DSS based on two-step variational-gradient method.

\section{ЛИТЕРАТУРА}

1. Самков О. В. Підтримка прийняття рішень в системі управління літального апарата / О.В.Самков, В. І. Сілков, О. П. Гожий, О. С. Мавренков // Збірник наукових праць Державного науково-дослідного інституту авіації. Київ : ДНДІА, 2012. Вип. (8)15, С. $104-109$.

2. Барабаш О. В. Нечіткі моделі опису ситуацій в системах автоматичного управління літальним апаратом / О. В. Барабаш, Д. М. Обідін, Р. В. Хращевський // Збірник наукових праць Військового інституту Київського національного університету імені Тараса Шевченка. Київ : ВІКНУ, 2012. № 38 , С. 6 - 13 .

3. Барабаш О. В. Модель баз знань інтелектуальної системи управління високошвидкісного рухомого об'єкта на основі ії верифікації / О. В. Барабаш, Д. М. Обідін, А. П. Мусієнко // Системи обробки інформації : збірник наукових праць. Харків : ХУПС, 2004.№ 5 (121), С. 3 -6.

4. Analytical Assessment of Security Level of Distributed and Scalable Computer Systems / Hu Z., Mukhin V., Kornaga Y., Barabash O., Herasymenko O. // International Journal of Intelligent Systems and Applications. 2016. Vol. 8, № 12, P. 57 - 64.

5. Dynamic Stability and Control of a Manipulating Unmanned Aerial Vehicle / Yunping L., Xijie H., Yonghong Z., Yukang Z. // International Journal of Aerospace Engineering Volume. 2018. Article ID 3481328, $13 \quad$ pages.https://doi.org/10.1155/2018/3481328.

6. Cummings M. L., Brzezinski A. M. Global vs. local decision support for multiple independent UAV schedule management // Int. J. Applied Decision Sciences. 2010. Vol. 3, No. 3,P.188-205.

7. Ильюшко В. М. Беспилотные летательные аппараты: Методики приближенных расчетов основных параметров и характеристик / В.М. Ильюшко, М. М. Митрахович, А. В. Самков, В. И. Силков и др.; под общ. ред. В. И. Силкова. Київ : ЦНДІОВТЗСУкраїни, 2012. 302 с.

8. Gunchenko Yu. A., Kovalets I.V., Shvorov S.A., Komarchuk D.S., Lukin V.E. (2017) Decision support system in planning and remote control of movement mobile objects. Informatics and mathematical methods in simulation, Vol. 7, №1-2,P. 127-134.

9. Barabash O. V., Dakhno N.B., Shevchenko H. V., Majsak T. V. (2017) Dynamic Models of Decision Support Systems for Controlling Unmanned Aerial Vehicles on the Basis of Two-Step Variation-Gradient Method. 2017 IEEE 4th International Conference Actual Problems of Unmanned Aerial Vehicles Developments, P. $108-111$.

10. Petryshyn W. V. On Class ofK-p.d. and Non-K-p.d. Operators and Operator Equation. / W. V. Petryshyn // Journal of Mathematical analysis and applications,1965. Vol.10, No 1, P.1-24.

11. Дахно Н.Б. Методика застосування однокроковоговаріаційно-градієнтного методу при аналізі диференціальних динамічних моделей СППР // Інформаційна безпека. - Луганськ : Східноукраїнський національний університет ім. В. Даля, 2014. № 2 (14), С. 150 - 156.

\section{REFERENCES}

1. Samkov O.V. Decision support in the aircraft control system / O. V. Samkov, V. I. Silkov, O. P. Gozhij, O. Ye. Mavrenkov // Collection of scientific papers of the State Research Institute of Aviation.- Kyiv : SRIA, 2012. Vol. (8)15,P. $104-109$.

2. Barabash O.V. Fuzzy Models for Describing Situations in Automatic Control Systems of an Aircraft / O. V. Barabash, D. M. Obidin, R. V. Hrashevskij // Collection of Scientific Papers of the Military Institute of Taras Shevchenko National University of Kiev, 2012. № 38, P. 6 - 13.

3. Barabash O.V. Knowledge Base Model of Intellectual Control System of High-Speed Moving Objects Based on its Verification / O.V. Barabash, D.M. Obidin, A.P. Musienko// Information

Processing Systems: digest of scientific works, 2004. № 5 (121), P. 3-6.

7. Ilyushko V.M. Unmanned aerial vehicles: Methods for approximate calculations of key parameters and characteristics / V. M. Ilyushko, M. M. Mitrahovich, A. V. Samkov, V. I. Silkov and etc.; under total ed. V. I. Silkov. Kyiv: CRI AME AF of Ukraine, 2012. $302 \mathrm{p}$.

11. Dakhno N.B.The method of application of one-step variationgradient method in the analysis of differential dynamic models of DSS // Information Security. - Lugansk: East Ukrainian National University. V. Dahl, 2014. № 2 (14), P. 150 - 156. 